\title{
Submission Receipt Date
}

National Cancer Institute

\section{Source}

National Cancer Institute. Submission Receipt Date. NCI Thesaurus. Code C94162.

The date (and time) on which the first submission unit is received by the regulatory authority. 